
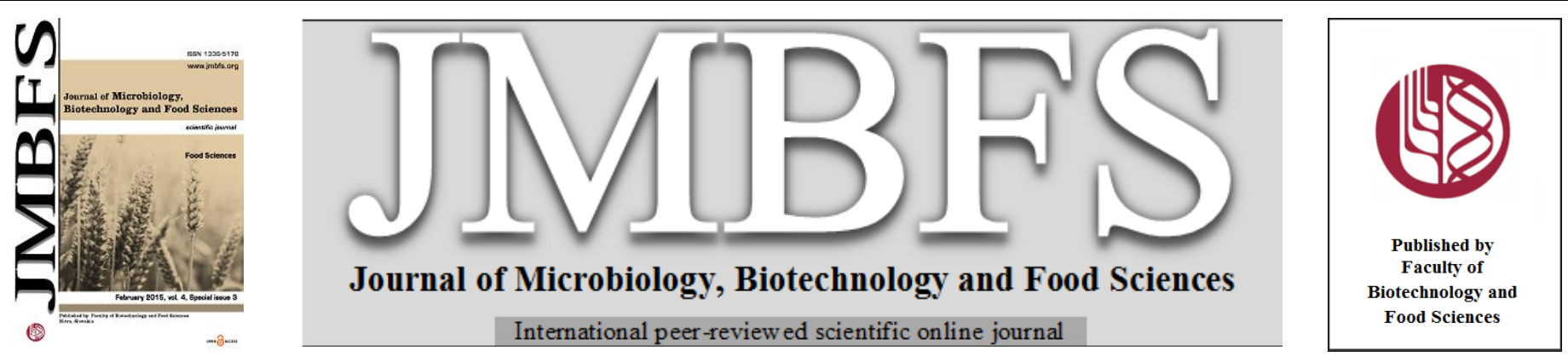

\title{
THE SCREENING OF CHROMIUM, LEAD, CADMIUM AND MERCURY IN YOGURTS
}

\section{Tomáš Tóth *, Miriama Kopernická, Marek Slávik, Luboš Harangozo, Veronika Csölleová}

Address(es): doc. RNDr. Ing. Tomáš Tóth, PhD.,

Slovak University of Agriculture in Nitra, Faculty of Biotechnology and Food Sciences, Department of Chemistry, Tr. A. Hlinku 2, 94976 Nitra, Slovakia, phone number: +4213764143.

*Corresponding author: tomas.toth@uniag.sk

doi: 10.15414/jmbfs.2015.4.special3.164-166

\section{ARTICLE INFO}

Received 29.11.2014

Revised 5. 12. 2014

Accepted 6. 12. 2014

Published 2.2. 2015

Regular article

open 2 access

\begin{abstract}
In our study, we have focused on monitoring the content of cromium, lead, cadmium and mercury in the 11 samples of yogurt, available in the sales network of the Slovak Republic and comparing it with the Highest PermissibleQuantity (HPQ). Samples of yogurt were mineralized by microwave digestion unit MARSX-press. Heavy metals were determined by at omic absorption spectrometer VARIAN $240 \mathrm{FS}$ and aut omatic mercury analyser AMA254. On the basis of our findings it was shown that the content of $\mathrm{Cr}, \mathrm{Pb}, \mathrm{Cd}$ and $\mathrm{Hg}$ of the samples do not exceeded the HPQ, the content of cromium was in the range of $0.000-0.250 \mathrm{mg} \cdot \mathrm{kg}^{-1}$, lead content was $0.000-$ $0.091 \mathrm{mg} \cdot \mathrm{kg}^{-1}$, cadmium content was $0.005-0.039 \mathrm{mg} \cdot \mathrm{kg}^{-1}$ and mercury content was $0.000144-0.003252 \mathrm{mg} \cdot \mathrm{kg}^{-1}$. The measured values were compared with the applicable legislative provisions for heavy metals maximum permissible levels of contaminants in yogurt by the food codex of Slovak Republic. During analysis, we found that none of the samples has exceeded the highest amount of all heavy metals in the food codex of the Slovak Republic.
\end{abstract}

Keywords: Heavy metals, chromium, lead, cadmium, mercury, yogurt

\section{INTRODUCTION}

People nowadays expect that the food was made from safe materials. Milk is among the basic foods that a person consumes just after birth as the mother's milk. Hygiene requirements for milk and milk products are laid down by legislation. Yoghurts are an important part of our food, they are fermented milk products and their composition contributes to the proper functioning of the digestive system. They are a source of calcium and vitamins of the B group. Yoghurts are the most popular products fermented with two functional groups of microorganisms that are related metabiosis. Already in the 19th century in Paris Ilja Iljich Mečnikov Russian doct or and director of the Pasteur Institute cultivated lactic acid bacterium that is called Lactobacillus bulgaricus, for which subsequently received the Nobel Prize. The one of functional food in Germany were yogurts in 1996 because of their health benefits (Zum Felde, 2004). Streptocuccus thermophilus at beginning of the fermentation and produces acidification causes growth subst ances having a stimulating effect on the growth of Lactobacillus delbrueckii subsp. bulgaricus. Second, Lactobacillus delbruecki subsp. bulgaricus hydrolysed with some amino acids, and thus promotes growth Streptocuccus termophilus. During symbiosis created unique aroma, which is caused by acetaldehyde of Lactobacillus delbrueckii subsp. bulgaricus (Gallo et al., 2013). Such microorganisms must be live, in a $1: 1$ or $1: 2$ in favor of Lactobacillus delbrueckii subsp. bulgaricus (Drábeková, Lengyelová, 2004). The contamination of milk and products thereof constitutes a large risk to humans. Nowadays places great emphasis on food especially the presence of foreign and toxic subst ances. Highest risk group consists of just heavy metals that accumulate in the body and cause serious disease.

Milk is a secretion of the mammary gland, which is product of cows, sheep, goats or buffaloes. Raw milk must not be heated above 40 degrees Celsius. Milk comprises $86-88 \%$ of water, dry mass contains $3-6 \%$ of fat, $3-4 \%$ of protein, $4-$ $5 \%$ of lactose and $0.7-0.8 \%$ of minerals. Fat free dry mass consists of minerals and lactose (Č uboň, 2012). The most of important minerals are zinc, copper, magnesium and iron. Their deficiency can cause pathological changes in the human body. Heavy metals are brought into the milk of animals such contaminants from agriculture and industry (Abou-Arab, 1997; Ebn et al. 2009). The yoghurt is often added a variety of fruit ingredients, which significantly affect the durability of the product (Palo, 1983). The heavy metal content in the fruit, that is used in the manufacture of yoghurt is a significant contaminant of these products (Stefanut et al., 2007). Heavy metals also affect physiological processes of fruit such as photosynthesis, respiration, and transpiration (Soceanu, 2009). The consumption of milk in Slovakia has a long tradition. The development of consumption of milk can be divided into two stages. By the year 2000, milk consumption has declined by around $60-162.4$ $\mathrm{kg}$ per person. In 2003 - 2004, consumption decreased by an average of $0.8 \mathrm{~kg}$ per person per year. The recommended dose of milk and milk product s is $220 \mathrm{~kg}$ per person per year (Kubicová, Dobák, 2012).

The aim of our work was to assess the extent of yogurt contamination by heavy metals.

\section{MATERIAL AND METHODS}

We used yogurt samples, commonly available in commercial net work in Slovak republic, to determine the contents of the risk elements (chromium, lead, cadmium, mercury).. We analysed 11 yogurt samples . Each sample an average of 1 gram was withdrawn from the commercial product. All of the samples were prior to the date of expiration. Description and characteristics of the analysed samples is given in table ( $\mathrm{T}$ ab 1$)$.

Determination of heavy metals in yogurt (excluding mercury)

Samples of yogurt were mineralized by wet road using microwave digestion unit MARS X-press. The end of determination was analysed by using atomic absorption spectrometer (VARIAN 240 FS, by Varian, Inc. USA).

Determination of mercury in yogurt

Mercury content was determined by aut omatic mercury analyzer AMA 254 (LECO Corporation), dedicated at omic absorption spectrophotometer for direct determination of mercury in solid and liquid samples.

The results of analyses were compared with the limit values that define the Food Code of the Slovak Republic No. 608/3/2004- 100 setting maximum levels for contaminants in foods). For statistical evaluation of results was used the program ST AT GRAFICS Plus 5.1 to process gained data (LSD test). 
Table 1 Description and characteristics of the analysed samples

\begin{tabular}{cccc}
\hline $\begin{array}{c}\text { Sample } \\
\text { number }\end{array}$ & Product name & Packing/weight & Country of origin \\
\hline 1 & TAMI - apricot & $180 \mathrm{~g}$ & Slovak Republic \\
\hline 2 & TESCO - currant & $140 \mathrm{~g}$ & Slovak Republic \\
\hline 3 & HOLLANDIA - BIO bananas & $180 \mathrm{~g}$ & Czech Republic \\
\hline 4 & UPDATE 1 - strawberry & $150 \mathrm{~g}$ & Hungary \\
\hline 5 & TAMI PROMINENT - pineapple & $135 \mathrm{~g}$ & Slovak Republic \\
\hline 6 & Goat's and sheep's milk yogurt - blueberry & $145 \mathrm{~g}$ & Unknown \\
\hline 7 & Sheep's milk yogurt - blueberry & $145 \mathrm{~g}$ & Unknown \\
\hline 8 & ZVOLENSKY - cranberry & $145 \mathrm{~g}$ & Slovak Republic \\
\hline 9 & DANONE - strawberry & $150 \mathrm{~g}$ & Czech Republic \\
\hline 10 & ZOTT JOGOBELLA LIGHT - roasted apple & $150 \mathrm{~g}$ & Germany \\
\hline 11 & MADET A - blueberry & $200 \mathrm{~g}$ & Czech Republic \\
\hline
\end{tabular}

\section{RESULTS AND DISCUSSION}

The lowest $\mathrm{Cr}$ content was measured in the sample No. 8 with a value of 0.000 mg.kg ${ }^{-1}$ and the highest $\mathrm{Cr}$ content was measured in the sample No. 10 with a value of $0.250 \mathrm{mg} \cdot \mathrm{kg}^{-1}$, which was not exceeded the limit value $0.500 \mathrm{mg} \cdot \mathrm{kg}^{-1}$ (Codex Alimentarius of the Slovak Republic). Results are shown in the figure 1.

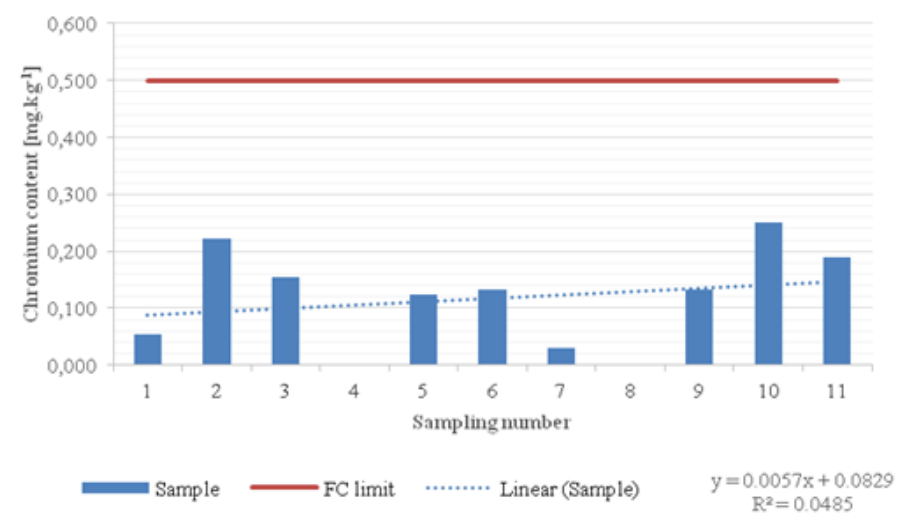

Figure 1 Chromium content in samples of yogurt $\left(\mathrm{mg} \cdot \mathrm{kg}^{-1}\right)$

The lowest Pbcontent was measured in the sample No. 5 with a value of 0.000 $\mathrm{mg} . \mathrm{kg}^{-1}$ and the highest $\mathrm{Pb}$ content was measured in the sample No. 7 with a value of $0.091 \mathrm{mg} \cdot \mathrm{kg}^{-1}$, which was not exceeded the limit value $0.300 \mathrm{mg} \cdot \mathrm{kg}^{-1}$ (Codex Alimentarius of the Slovak Republic) Results are shown in the figure 2.

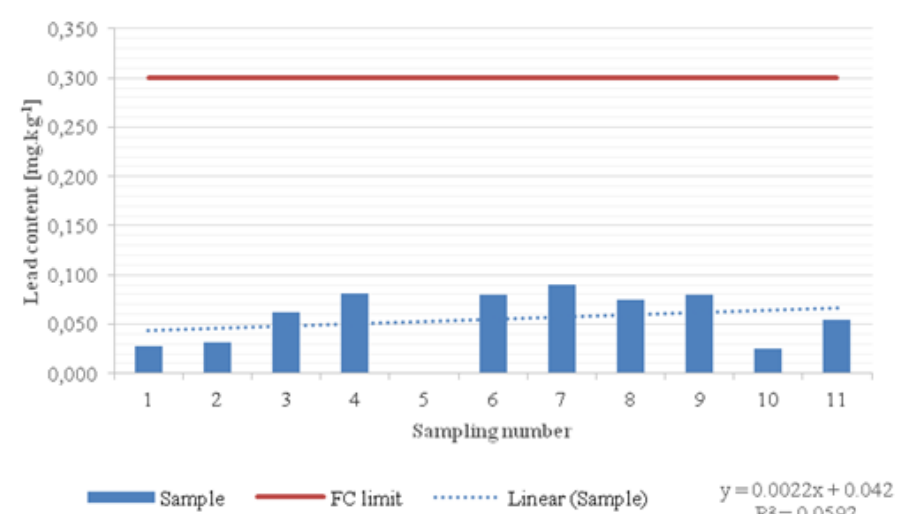

Figure 2 Lead content in samples of yogurt $\left(\mathrm{mg} \cdot \mathrm{kg}^{-1}\right)$

The lowest Cd content was measured in the sample No. 8 with a value of 0.005 $\mathrm{mg} . \mathrm{kg}^{-1}$ and the highest Cd content was measured in the sample No. 7 with value of $0.039 \mathrm{mg} . \mathrm{kg}^{-1}$, which was not exceeded the limit value $0.050 \mathrm{mg} \cdot \mathrm{kg}^{-1}$ (Codex Alimentarius of the Slovak Republic). Results are shown in the figure 3.

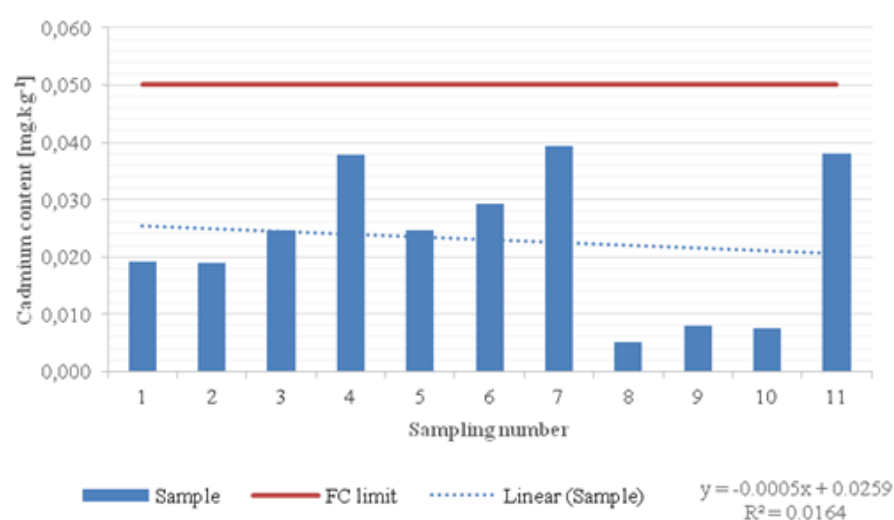

Figure 3 Cadmium content in samples of yogurt $\left(\mathrm{mg} \cdot \mathrm{kg}^{-1}\right)$

The lowest $\mathrm{Hg}$ content was measured in the sample No. 5 with a value of $0.000144 \mathrm{mg} \cdot \mathrm{kg}^{-1}$ and the highest $\mathrm{Hg}$ content was measured in the sample No. 3 with a value of $0.003252 \mathrm{mg} \cdot \mathrm{kg}^{-1}$, which was not exceeded the limit value 0.020 mg.kg ${ }^{-1}$ (Codex Alimentarius of the Slovak Republic). Results are shown in the figure 4 .

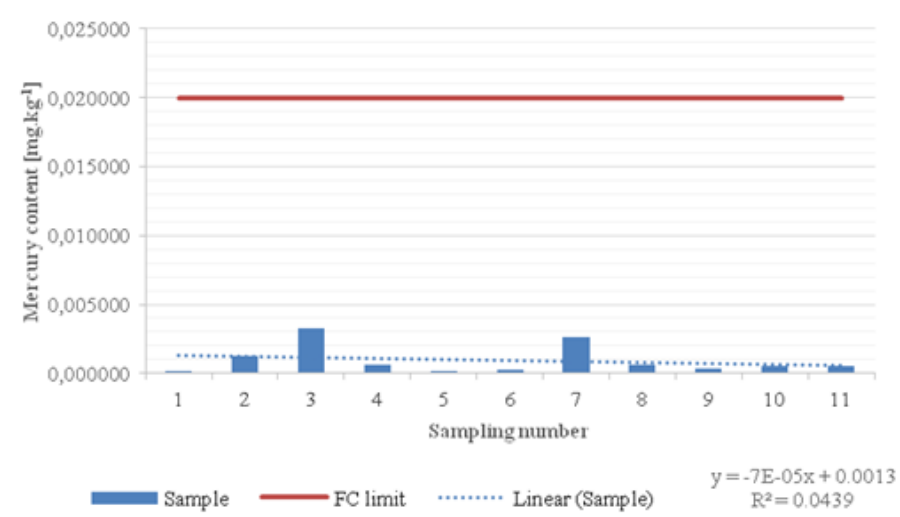

Figure 4 Mercury content in samples of yogurt $\left(\mathrm{mg} \cdot \mathrm{kg}^{-1}\right)$

In samples was not exceed the total content limit values of monitored heavy metals. Between samples number 4 and 8 , then 6 and 9 were not significant differences $(P>0.05)$ in the concentration of chromium. Between samples number 1,2 and 10 , then 3 and 11 and finally 4, 6, 8 and 9 were not significant differences $(\mathrm{P}>0.05)$ in the concentration of lead, bet ween samples number 8,9 and 10 , then 1 and 2, after then 3,5 and 6 and finally 4,7 and 11 were not significant differences $(\mathrm{P}>0.0) 5$ in the concentration of cadmium and in the case of the concentration of mercury between samples number 1 and 5 were not significant differences ( $\mathrm{Tab} 2)$. 
Table 2 Level of the concentration significance of $\mathrm{Cr}, \mathrm{Pb}, \mathrm{Cd}$ and $\mathrm{Hg}$ in yogurt

\begin{tabular}{|c|c|c|c|c|}
\hline \multirow{2}{*}{ Sample } & \multicolumn{4}{|c|}{ Heavy metal content } \\
\hline & $\mathrm{Cr}\left[\mathrm{mg} \cdot \mathrm{kg}^{-1}\right]$ & $\mathrm{Pb}\left[\mathrm{mg} . \mathrm{kg}^{-1}\right]$ & Cd [mg.kg $\left.{ }^{-1}\right]$ & Hg [mg.kg $\left.{ }^{-1}\right]$ \\
\hline 1 & $0,055 \mathrm{c}$ & $0,027 \mathrm{~b}$ & $0,019 \mathrm{~b}$ & $0,000148 \mathrm{a}$ \\
\hline 2 & $0,222 \mathrm{~h}$ & $0,032 \mathrm{~b}$ & $0,019 \mathrm{~b}$ & $0,001267 \mathrm{~h}$ \\
\hline 3 & $0,154 \mathrm{f}$ & $0,062 \mathrm{c}$ & $0,025 \mathrm{c}$ & $0,003252 \mathrm{j}$ \\
\hline 4 & $0,000 \mathrm{a}$ & $0,081 \mathrm{~d}$ & $0,038 \mathrm{~d}$ & $0,000655 \mathrm{~g}$ \\
\hline 5 & $0,123 \mathrm{~d}$ & $0,000 \mathrm{a}$ & $0,025 \mathrm{c}$ & $0,000144 \mathrm{a}$ \\
\hline 6 & $0,133 \mathrm{e}$ & $0,080 \mathrm{~d}$ & $0,029 \mathrm{c}$ & $0,000264 \mathrm{~b}$ \\
\hline 7 & $0,030 \mathrm{~b}$ & $0,091 \mathrm{e}$ & $0,039 \mathrm{~d}$ & $0,002666 \mathrm{i}$ \\
\hline 8 & $0,000 \mathrm{a}$ & $0,075 \mathrm{~d}$ & $0,005 \mathrm{a}$ & $0,000646 \mathrm{f}$ \\
\hline 9 & $0,133 \mathrm{e}$ & $0,080 \mathrm{~d}$ & $0,008 \mathrm{a}$ & $0,000348 \mathrm{c}$ \\
\hline 10 & $0,250 \mathrm{i}$ & $0,025 \mathrm{~b}$ & $0,008 \mathrm{a}$ & $0,000520 \mathrm{~d}$ \\
\hline 11 & $0,190 \mathrm{~g}$ & $0,054 \mathrm{c}$ & $0,038 \mathrm{~d}$ & $0,000529 \mathrm{e}$ \\
\hline Mean & $0,117 \pm 0,086$ & $0,055 \pm 0,030$ & $0,023 \pm 0,013$ & $0,000949 \pm 0,001049$ \\
\hline HD 0,05 & 0,0063563 & 0,0074745 & 0,0045379 & 0,0000043 \\
\hline
\end{tabular}

We cannot observe statistical significant of the correlations. Chromium, lead, cadmium either mercury content were not influenced by particular samples ( $\mathrm{T} a b$

3). Cr content was strong statistically significant influenced by $\mathrm{Pb}$ content. $\mathrm{Cr}$ content was not statistically significant influenced by $\mathrm{Cd}$ and $\mathrm{Hg}$ content. With increasing $\mathrm{Cr}$ content, the content of $\mathrm{Pb}$ decrease ( $\mathrm{Tab} 4) . \mathrm{Cd}$ content was not statistically significant influenced by $\mathrm{Cr}, \mathrm{Pb}$ either $\mathrm{Hg}$ content ( $\mathrm{Tab} 4) . \mathrm{Hg}$ content was not statistically significant influenced by $\mathrm{Cr}, \mathrm{Pb}$ either $\mathrm{Cd}$ content ( $\mathrm{Tab} 4)$.

Table 3 Pearson correlation coefficient between samples and heavy metal content

\begin{tabular}{lll}
\hline & Parameter & Correlation coefficient (r) \\
\hline Dependent variable & Independent variable & 0,2199 \\
\cline { 2 - 3 } Sample & $\mathrm{Cr}$ & 0,2510 \\
\cline { 2 - 3 } & $\mathrm{Pb}$ & $-0,1236$ \\
\cline { 2 - 3 } & $\mathrm{Cd}$ & $-0,2095$ \\
\cline { 2 - 3 }
\end{tabular}

Table 4 Pearson correlation coefficient between $\mathrm{Cr}, \mathrm{Cd}, \mathrm{Pb}, \mathrm{Hg}$ and other heavy metal content

\begin{tabular}{lll} 
Table 4 Pearson correlation coefficient & between $\mathrm{Cr}, \mathrm{Cd}, \mathrm{Pb}, \mathrm{Hg}$ and other heavy metal content \\
\hline \multirow{3}{*}{$\mathrm{Cr}$} & $\mathrm{Pb}$ & $-0,4900^{* *}$ \\
\cline { 2 - 3 } & $\mathrm{Cd}$ & $-0,2012$ \\
\cline { 2 - 3 } & $\mathrm{Hg}$ & $-0,0269$ \\
\hline \multirow{2}{*}{$\mathrm{Pb}$} & $\mathrm{Cr}$ & $-0,4900^{* *}$ \\
\cline { 2 - 3 } & $\mathrm{Cd}$ & 0,2423 \\
\cline { 2 - 3 } & $\mathrm{Hg}$ & 0,3081 \\
\hline \multirow{3}{*}{$\mathrm{Cd}$} & $\mathrm{Cr}$ & $-0,2012$ \\
\cline { 2 - 3 } & $\mathrm{Pb}$ & 0,1744 \\
\cline { 2 - 3 } & $\mathrm{Hg}$ & 0,2891 \\
\hline \multirow{3}{*}{$\mathrm{Hg}$} & $\mathrm{Cr}$ & $-0,0269$ \\
\cline { 2 - 3 } & $\mathrm{Pb}$ & 0,3081 \\
\cline { 2 - 3 } & $\mathrm{Cd}$ & 0,2891 \\
\hline
\end{tabular}

**strong statistical significant of the correlations, *statistical significant of the correlations

Analyses of literature showed that the published studies on migration of heavy metals in the system soil and fruits are up to date. The increased soil acidity, depressed topography, overgrown agricultural fields, decline in the level of farming practices, and inefficient use of chemical agents protecting plants from pests, diseases, and rodents promote a greater accumulation of heavy metals in fruits (Dubovik, 2009). Authors showed that consumption of milk products is nearly free of risks, but bioaccumulation of heavy metal through the food chain and intake from other food stuff should also be of concern (Arafa M. S. Meshref et al., 2014)

\section{CONCLUSION}

The research was carried out by analyzing samples of yogurt available in commercial networks in Slovakia. Sampling was random and was tasked with the most different representation of products. The tested samples of yogurt do not pose a risk of heavy metal entry as a part of nutrition and thus a threat for human health.

Acknowledgments: This work was supported by the project VEGA 1/0630/13 and KEGA 014SPU-4/2013.

\section{REFERENCES}

ABOU-ARAB, A. A. K. 1997. Effects of Ras cheese manufacturing on the stability of DDT and it metabolites. Journal offood chemistry.59(1). 115-119. http://dx.doi.org/10.1016/s0308-8146(96)00214-2

ARAFA, M. S. Meshref, W ALLA, A. Moselhy, NOUR EL-HOUDA, Y. Hassan, 2014. Heavy metals and trace elements levels in milk and milk products. Journal of food measurement and characterization. 2013 (7). 2193-4126. http://dx.doi.org/10.1007/s1 1694-014-9203-6

ČUBOŇ, J., HAŠČÍK, P., KAČÁNIOVÁ, M. 2012. Hodnotenie surovín a potravín živočíšneho pôvodu. Nitra : Slovenská pol’nohospodárska univerzita 381 s. ISBN 978-80-552-0870-1.
DRÁBEKOVÁ, J., LENGYELOVÁ, L. 2004. Jogurt ako súčast' zdravej výživy (Zborník z vedecko-metodickej konferencie), Výchova k zdravému životnému štýlu) Nitra : FPV UKF, 65-70. ISBN 80-8050-739-2.

DUBOVIK, V. A. 2009. Migration of heavy metals in the system soil-apple leaves-fruits. Russian agricultural sciences. 35(5). 331-333. http://dx.doi.org/10.3103/s1068367409050127

EBN, A., ABOU DONIA, M. A., ABD-RABOU, N. S., ABOU-ARAB, A. A. K. EL-SENAIT Y, M. H. 2009. Chemical composition of raw milk and heavy metals behavior during processingbof milk products. Global veterinaria, 3(3), 368-275. ISSN 1992-6197.

Codex Alimentarius, 2014, http://www.svps.sk/legislativa/legislativa kodex.asp GALLO, J., VRABEC, M., DUDRIKOVÁ, E. 2013. Hodnotenie jogurtov vyrobených z kozieho mlieka v laboratórnych podmienkach. Slovensky veretinárny časopis, 38(1-2), 82. ISSN 1335-0099.

KUBICOVÁ, L., DOBÁK, D. 2012. Vývoj a úroveň spotreby mlieka a mliečnych výrobkov v SR a modelovanie dopytu po potravinách vo vybraných skupinách domácnosti. Nitra: Slovenskápol'nohospodárska univerzita, 42-43. ISBN 978-80-552-0821-3.

PALO, V. 1983. Chémia a technológia mlieka - návody a cvičenia. Bratislava SVŠT, 217 s. ISBN 9788022700627.

SOCEANU, A. 2009. Presence of heavy metals in fruits from Pronus genera. Ovidius university annals of chemistry, 20(1), 108-110. ISSN 1223-7221. STEFANUT, M. N., DAVID, I., ST ANOIEV, Z., MACARIE, C. 2007. The monit oring of heavy metals in fruits. Chemical bulletin Polytechnica university of Timisoara, 52(1-2), 147-151.

ZUM FELDE, L'. 2004. Funkčné potraviny na postupe. Slovenský výber, 8(2), 2829. ISSN 1335-9266. 